REVISTA CIENCIAS BIOMÉDICAS

EDITORIAL

2015;6(1): 9-10

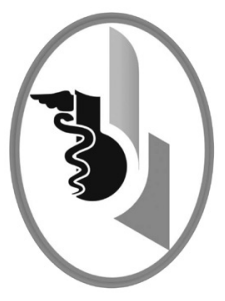

\title{
EVOLUCIÓN DE LA TERAPIA SUSTITUTIVA RENAL
}

\section{EVOLUTION OF THE RENAL REPLACEMENT THERAPY}

La enfermedad renal crónica (ERC) es un problema de salud pública mundial. La cuenta de alto costo de Colombia a 2013 reportó la existencia de 22.926 pacientes en terapia de diálisis, 5.941 con trasplante renal y 1.015 .124 pacientes con ERC en estadios I - IV, potenciales a progresar y requerir terapia sustitutiva renal (TSR), para una incidencia aproximada de ingreso a diálisis de 65 personas por millón de

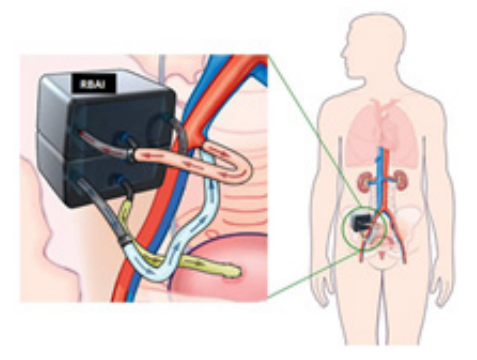
habitantes (1). En Estados Unidos en el 2011 se encontraban en diálisis 430.723 pacientes y 185.626 estaban trasplantados (2).

En 1945 Willen Kolff realizó la primera sesión de hemodiálisis con éxito. La cual ha ido evolucionando desde el uso en pacientes agudos hasta la aplicación en crónicos. En 1972 se aprobó en EEUU la hemodiálisis crónica para el tratamiento de todos los pacientes con ERC avanzada (3).

Desde entonces la diálisis en sus dos modalidades (hemodiálisis y peritoneal), así como el trasplante renal, es la base del manejo de pacientes con ERC avanzada. La diálisis mejora la calidad de vida de los pacientes, no obstante continúa siendo alta la tasa de complicaciones y solo brinda reemplazo de la función excretora del riñón.

En 1954 Murray realizó el primer trasplante renal exitoso en humanos. El trasplante renal es la terapia ideal, pero no está excepta de complicaciones infecciosas, riesgo de neoplasias y efectos colaterales asociados a los medicamentos inmunosupresores que deben acompañarlo. En Estados Unidos, existen 100.000 pacientes en espera de trasplante renal, con probabilidad acumulativa de recibirlo del $9.6 \%$ en el primer año, del 21.6 y $36.0 \%$ para después de tres y cinco años, respectivamente, lo cual demuestra la alta demanda insatisfecha. El promedio de espera para el trasplante renal es entre tres y seis años (4).

Buscando mejorar las terapias de diálisis, para lograr además de la función excretora aportar a las funciones metabólicas y endocrinas renales, la medicina regenerativa y la bioingeniería, tratan de obtener nuevos modelos de TSR. Aebischer (1987) desarrolló en un modelo de daño renal agudo en perros, el riñón bioartificial (RBA), que combina la hemofiltración convencional con un dispositivo que aporta células epiteliales renales. Demostró la capacidad para cumplir función excretora, regulación de electrolitos y producción de vitamina D3. En 1999 Humes enriqueció el dispositivo utilizando células del túbulo renal proximal, permitiendo además el transporte de sodio, glucosa y aniones orgánicos.

El RBA se ha utilizado en estudios de Fase I y II en pacientes con daño renal agudo, demostrándose mayor supervivencia comparados con pacientes que solo recibían hemofiltración. Ello fue una ventaja, pero no 
una solución. Se presentaron dificultades para la fabricación del dispositivo, costos elevados, dificultad para conservar viables a largo plazo las células y en el diseño del estudio clínico (5).

En el 2012, Buffintong creó el sistema: Células Epiteliales Renales Bioartificial (BRECS), un perfusor de células epiteliales renales primarias en crecimiento sobre una membrana porosa criopreservada. Este dispositivo permitió el desarrollo del RBA y el implantable (RBAI).

El RBAP consiste en un sistema de regeneración que reemplaza la función excretora del riñón y de un BRECS que reemplaza la función metabólica y endocrina renal. Son dispositivos de fácil transporte y no requieren sistemas alimentadores de agua o de drenaje. No han mostrado beneficio para eliminar toxinas urémicas ligadas a proteínas, pero su perfeccionamiento puede ser importante para el tratamiento de los pacientes con daño renal agudo o crónico (6).

A su vez el RBAI, que combina un hemofiltro y un bioreactor de células renales implantables, sería la solución a las limitaciones actuales del trasplante renal, brindando además una alternativa a la carga de la hemodiálisis crónica. Tiene dos limitaciones: la bomba que requieren y la necesidad de filtros que mantengan el equilibrio entre la permeabilidad al agua y la fuga de albúmina y otras macromoléculas.

Por requerirse perfusión vascular para mantener la filtración y la viabilidad de las células, el RBAI se diseña para implantar en los vasos ilíacos, como se realiza con los trasplantes actuales. Alimentado por el torrente sanguíneo el RBAI, deja la sangre libre de toxinas y el ultrafiltrado pasa directamente a la vejiga. Se estudian aspectos referentes al autocuidado del dispositivo implantado, el ciclo de vida del aparato, la manera de ser mínimamente invasivo para reemplazar componentes y cómo preservar la vasculatura para futuros transplantes.

Song (2013), describió que a ratas con ERC [previamente sometidos sus riñones a lavado con detergentes para destruir el componente celular, dejando intactos vasculatura y túbulos], les sembraron células stem capaces de regenerar células renales, resultando un riñón capaz de producir orina. El estudio abre puertas y resuelve dificultades del dispositivo mecánico, permitiría el uso masivo en pacientes con ERC, sustituiría la diálisis, brindaría además de la función excretora las otras funciones del riñón y con ello mejoría en la calidad de vida (7).
El xenotrasplante a partir de riñones de cerdo es otra alternativa, no obstante que existen serias limitaciones por la intolerancia inmunológica y solo se ha logrado supervivencia hasta por tres meses, de injertos en primates no humanos (8).

Lo mejor es prevenir la pérdida de la función renal, con programas bien estructurados para reducir o evitar las patologías que comprometan su integridad. Sin embargo, la alta prevalencia e incremento de enfermedades como la diabetes mellitus y la hipertensión arterial, hacen que sea de esperar que siga creciendo en las próximas décadas el número de pacientes perderán la función renal. Se requieren mejores alternativa que la diálisis actual, que brinden funciones cercanas a las que cumplen los riñones nativos, para mejorar más la supervivencia y la calidad de vida de los pacientes con ERC.

\section{REFERENCIAS BIBLIOGRÁFICAS}

1. Cuenta de alto costo. Fondo colombiano de enfermedades de alto costo. [internet]. Colombia: cuenta de alto costo; 2014 [consultado 2014 octubre 19].disponible en: http://www.cuentadealtocosto. org/byblos/docs/situacion_de_la_enfermedad_renal_cronica_2013.pdf

2. U.S. Renal Data System, USRDS 2013 Annual Data Report: Atlas of Chronic Kidney Disease and EndStage Renal Disease in the United States, National Institutes of Health, National Institute of Diabetes and Digestive and Kidney Diseases, Bethesda, MD, 2013.

3. Cameron JS. Breve historia de la hemodiálisis (1850-1970). Hombres, materiales e ideas. En: Valderrabano F, editor. Tratado de hemodiálisis. España: Editorial Médica Jims S.L; 1999. p.1-27.

4. Orlando G, Soker S, Stratta RJ and Atala A. Will Regenerative Medicine Replace Transplantation? Cold Spring Harb Perspect Med. 2013;3: 1-14.

5. Jansen J, Fedecostante $M$, Wilmer $M J$, van den Heuvel LP, Hoenderop JG, Masereeuw R. Biotechnological challenges of bioartificial kidney engineering. Biotechnol Adv. 2014; 32(7):1317-27.

6. Humes HD, Buffington D, Westover AJ, Roy S, Fissell WH. The bioartificial kidney: current status and future promise. Pediatr Nephrol. 2014; 29(3):34351.

7. Song J, Guyette J, Gilpin S, González G, Vacanti J, Ott H. Regeneration and experimental orthotopic transplantation of a bioengineered kidney. Nat Med. 2013; 19(5): 646-51. doi: 10.138/nm.3154.

8. Cowan PJ, Cooper DK, d'Apice AJ. Kidney xenotransplantation. Kidney Int. 2014; 85(2): 265-75.

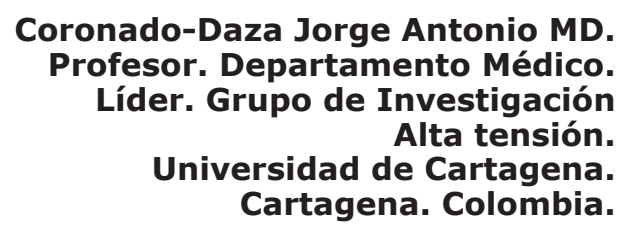


REVISTA CIENCIAS BIOMÉDICAS

\section{EDITORIAL}

2015;6(1): 11-12

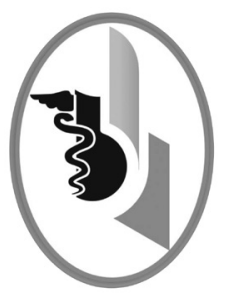

\section{EVOLUTION OF THE RENAL REPLACEMENT THERAPY}

The chronic renal disease (CRD) is a public health problem worldwide. The check of high costs of Colombia for 2013 reported the existence of 22.926 patients in dialysis therapy, 5.941 with kidney transplantation and 1.015.124 patients with CRD in stages I - IV, with possibility of progressing and to require renal replacement therapy (RRT), for an incidence approximate of ingress to

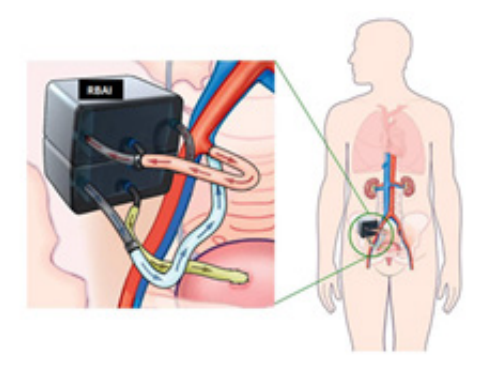
dialysis of 65 people per million of habitants (1). In the United States in $2011,430.723$ patients were in dialysis and 185.626 were transplanted (2).

In 1954 Murray carried out the first successful kidney transplantation in humans and in 1945 Willen Kolff carried out the first session of hemodialysis with success. The hemodialysis was progressing since the use in acute patients until its application in chronic patients. In 1972 in EEUU, the chronic hemodialysis was approved for the treatment of all patients with advanced CRD (3).

Since then, the dialysis in its two modalities (hemodialysis and peritoneal dialysis) just as the kidney transplantation, are the base of the management of patients with advance CRD. Although dialysis improves the quality of life of patients, the complication rate continues being high and it only offers replacement of the renal excretory function.

The kidney transplantation is the ideal therapy, but it is not exempt of infectious complications, neoplasms risk and adverse effects associated to the immunosuppressive drugs that must accompanied it. In EEUU, 100.000 patients are waiting for a kidney transplantation with accumulative probability of receiving it in $9.6 \%$ in the first year, 21.6 and $36.0 \%$ in the third and fifth year respectively, which demonstrates the high unsatisfied demand. The average waiting time for the kidney transplantation in between three and six years (4).

Searching to improve the dialysis therapies to achieve the renal metabolic and endocrine functions, the regenerative medicine and the bioengineering pretend to obtain new models of RRT. Aebischer (1987) developed a model of acute renal damage in dogs, the bioartificial kidney (BAK), which combines the conventional hemofiltration with a device that provides renal epithelial cells. It demonstrated the capacity to carry out excretory function, electrolytes regulation and vitamin D production. In 1999 Humes transformed the device using cells of the renal proximal tubule allowing the sodium, glucose and organic anions transportation.

The RBA has been used in humans in phase I and II studies in patients with acute renal damage, demonstrating higher survival in comparison with patients that only received hemofiltration. That was an advantage, but not a solution. For the manufacture of the device some difficulties 
were found, just as high costs, problems to conserve the cells for long time and to design the clinical trial (5).

In 2012, Buffintong designed the Bioartificial renal epithelial cells system (BRECS), an all-inone culture vessel, cryostorage device, and cell therapy delivery system. This device allowed the developed of portable RBA (PRBA) and an implantable one (IRBA).

The PRBA consists in a regeneration system that replaces the excretory renal function and a BRECS that replaces the metabolic and endocrine renal function. They are devices of easy transportation and do not require feeder systems of water or drainage. They have not showed benefits to eliminate protein-bound uremic toxins but their improvement could be important to the treatment of patients with acute or chronic renal damage (6).

In turn the IRBA, which combines a hemofilter and a bioreactor of implantable renal cells, would be the solution to the current limitations of the renal transplantation, affording also an alternative to the charge of the chronic hemodialysis. It has two limitations: the pump that require and the necessity of filters that maintain the balance between the water permeability and the escape of albumin and other macromolecules.

Due to vascular perfusion is required to maintain the filtration and the viability of the cells, the RBAI is designed to implant in the iliac vessels, as it is done in the current transplantation. When it is fed by the blood, the IRBA cleans the blood of toxins and the ultrafiltration goes directly to the bladder. And aspects concerning to the self-care of the implanted device, the life cycle of the device, the minimum way to replace its components and how to preserve the vessels are studied to future transplantation.

Song (2013) described that in rats with CRD (with kidney previously subjected to irrigation with detergents to destroy the cellular component, allowing to be intact the blood supply and tubules), sowed stem cells able to regenerate renal cells, resulting a kidney able to produce urine. The study opens doors and resolves the difficulties of the mechanic device and allows the massive use in CRD patients. It will substitute the dialysis, will offer besides the excretory function the other renal functions and with that it will improve in the quality of life (7).
The xenotransplant from the pig kidney is other alternative, however there are serious limitations due to the immunologic intolerance, only survival until three months has been achieved with grafts in non-human primates (8).

The best is to prevent the loss of the renal function with well-structured programs to reduce or to avoid the pathologies that compromise their integrity. However, the high prevalence and increase of diseases as diabetes mellitus and arterial hypertension, do that the number of patients without a good renal function increases. Better alternatives than current dialysis are required that offer similar functions to those carried out by a native kidney to improve the survival and the quality of life of patients with CRD.

\section{BIBLIOGRAPHIC REFERENCES}

1. Cuenta de alto costo. Fondo colombiano de enfermedades de alto costo. [internet]. Colombia: cuenta de alto costo; 2014 [consultado 2014 octubre 19].disponible en: http://www.cuentadealtocosto. org/byblos/docs/situacion_de_la_enfermedad_renal_cronica_2013.pdf

2. U.S. Renal Data System, USRDS 2013 Annual Data Report: Atlas of Chronic Kidney Disease and EndStage Renal Disease in the United States, National Institutes of Health, National Institute of Diabetes and Digestive and Kidney Diseases, Bethesda, MD, 2013.

3. Cameron JS. Breve historia de la hemodiálisis (1850-1970). Hombres, materiales e ideas. En: Valderrabano F, editor. Tratado de hemodiálisis. España: Editorial Médica Jims S.L; 1999. p.1-27.

4. Orlando G, Soker S, Stratta RJ and Atala A. Will Regenerative Medicine Replace Transplantation? Cold Spring Harb Perspect Med. 2013;3: 1-14.

5. Jansen J, Fedecostante M, Wilmer MJ, van den Heuvel LP, Hoenderop JG, Masereeuw R. Biotechnological challenges of bioartificial kidney engineering. Biotechnol Adv. 2014; 32(7):1317-27.

6. Humes HD, Buffington D, Westover AJ, Roy S, Fissell WH. The bioartificial kidney: current status and future promise. Pediatr Nephrol. 2014; 29(3):34351.

7. Song J, Guyette J, Gilpin S, González G, Vacanti J, Ott H. Regeneration and experimental orthotopic transplantation of a bioengineered kidney. Nat Med. 2013; 19(5): 646-51. doi: 10.138/nm.3154.

8. Cowan PJ, Cooper DK, d'Apice AJ. Kidney xenotransplantation. Kidney Int. 2014; 85(2): 265-75.

\section{Jorge Antonio Coronado Daza. MD. Profesor. Departamento Médico. Líder. Grupo de Investigación Alta tensión. Universidad de Cartagena. Cartagena. Colombia.}

